\title{
CARSOLOGICA SINICA OPENS TO THE WORLD (SPECIAL ISSUE 2016)
}

\author{
Andrej KRANJC
}

Carsologica Sinica, the main karstological journal in China is edited by the Institute of Karst Geology at Guilin for 35 years already, under the sponsorship of the Chinese Academy of Geological Sciences, Institute of Karst Geology, International Research Centre on Karst, Commission of Karst Geology, and Committee of Speleology of Geological Society of China. Similar to Acta carsologica, its start was modest, regarding design as well as content. It is self understanding that it was completely in Chinese language, in short exclusively Chinese journal Zhongguo Yanrong. In the 80-ties of the last century contacts with western karstologists started and strengthened. Carsologica Sinica followed those trends. Through years it changed in getting more modern design. Today it looks like any modern solid professional journal: large format, two-column page, colour, graphs, photos and maps, nice colour cover picture different every year, with four or six even numbers per year. Differently than many western karstological and speleological journals Carsologica Sinica is issued regularly, without any delay.

Of course, content is more important than appearance. Gradually papers were no more exclusively in Chinese. At first abstracts and summaries in English appeared, occasionally captures to figures and legends to illustrations, and the whole text in English. Let me mention just the volume 25 (2006) where papers of the international conference on big collapse depressions tian kengs are published. Papers of Chinese authors were published in Chinese, others in English. Editorial Board of the journal incorporated some leading foreign karstologists D. Ford, P. Williams, A. Tyc, and N. Goldscheider for example. Even papers on the development of karst depressions terminology and on the origin of the term karst were published in English, to mention just some.

And now was published a special number of the volume 35 (2016), dedicated to the $35^{\text {th }}$ International Geological Congress at Cape Town, full in English. In the Preface the Editor-in-Chief wrote that "the Editorial Board hope, that the special edition may not only introduce the latest progress made in the field of karst by China, but also introduce the present major research fields and service for karst in China”. This number with 186 pages is larger than regular ones. It contains 19 papers of Chinese authors, well known to Western colleagues too, as Cao Jian-hua, Zhang Cheng, Liu Hong, and Jiang

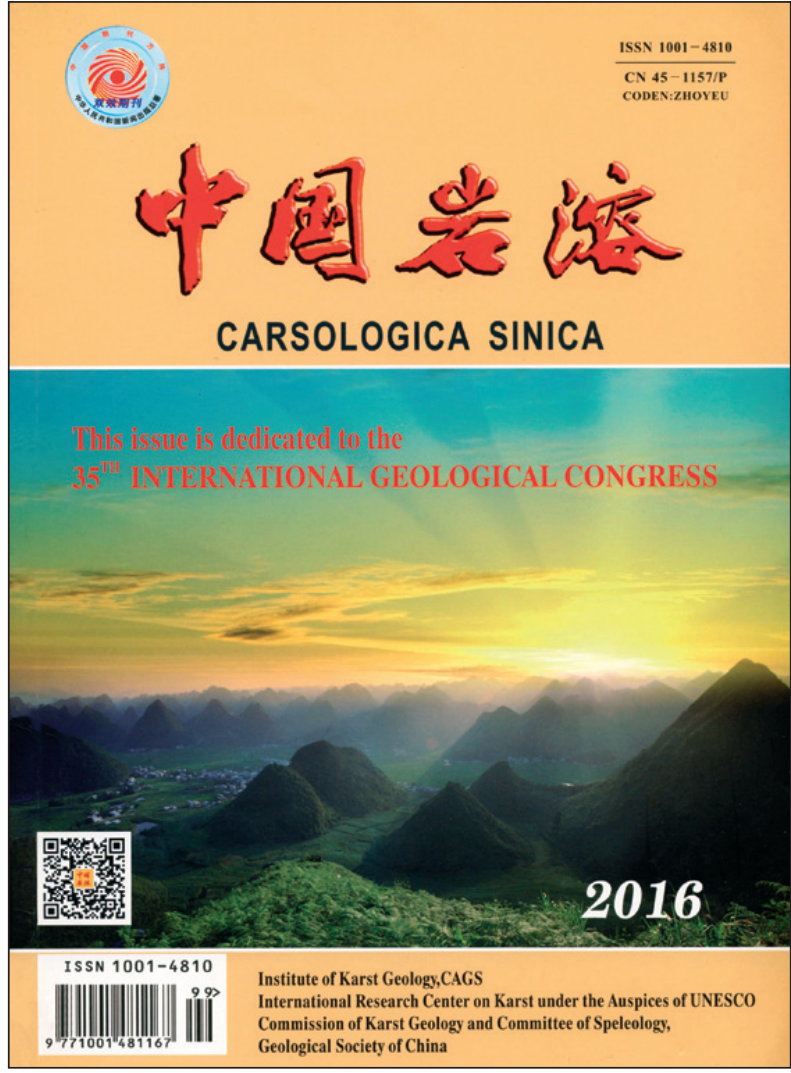

Zhong-cheng. Some of papers are real basic studies as "Research progress on response of karst cave drip water to surface environments « on 13 pages. It has 86 references, 26 of them of non-Chinese authors. As the Editorin-Chief said that this special issue does not show »the latest progress made in the field of karst by China « only but is a sort of overview of the Chinese karst, of some of its characteristics and particularities. The first paper presents essential results of the international project on carbon cycle, co-ordinated by karstologists of Guilin Institute. There are other two papers dealing with carbon, one about capacity and suitability of $\mathrm{CO}_{2}$ geological storage and the second one about distribution of soil organic carbon. Majority of papers is dedicated to karst water. They present studies on percolating and karst underground water, on impact of karst water on environment, on karst water chemistry, and on content of polycyclic aromatic hydrocarbons (PAH) in the underground river in the bottom of the deepest »tiankeng « Dashiwei. 
The topic of another four papers are karst morphology, collapsed dolines, Ordovician karst geomorphology and oil reservoir characteristics, and on the genesis of the well known show cave Shihua not far from Beijing. Two biological articles present results of bryophyte communities and of microbial biomass carbon study. Directly connected to human activities on karst are papers on desertification of karst terrains and on agricultural sustainable development. Overview papers do not present necessarily the results for the whole karst of China; it is too big and too heterogeneous, but in some cases for large parts of the country. Such papers are A review of karst groundwater of Southern China and Current situation and measures of karst collapse in China. The first includes the map Karst of China regarding the geological structure and the map Distribution of underground rivers in South China. Other examples are highly specialised papers taking into account small regions or case studies and therefore presenting results much more in details. Apart of the mentioned papers on Existing conditions of PAHs... and Space structure and evolution of Shihua Cave the attention deserves also the paper Distribution of soil organic carbon...a case study of Beibei district. For general public maybe the details and the results themselves are not so interesting and important as understanding and acquaintance with methods, research equipment, and instrumentation operated by Chinese researchers. In the first case researchers analysed $16 \mathrm{PAH}$ from the samples taken the whole year or 120 days respectively of air, soil and water. Survey and analyse of the Shihua Cave were performed by Leica Laser Rangefinders with the support of Arcmap 10 and Onstation cave drawing software. Research of soil carbon was carried on different types of land surface in different altitudes. All soil profiles under different vegetation cover (forest, meadow, kitchen garden, orchard, and field) have been analysed.

Just one such issue of Carsologica Sinica as the present one can inform non-Chinese readers more than 35 volumes in Chinese. We are really wishing that our Chinese friends-karstologists will publish more special issues in future. It would be ideal if the editor can edit a special issue once a year where the most important papers during the current year would be published in English.

Andrej Kranjc 